\title{
Discussion on the Construction of Practical Teaching System of College Media in the New Media Environment
}

\author{
Nan Wu \\ Nanyang Institute of Technology; Nanyang Henan 473000 China.
}

Keywords: Colleges and universities; media; practical teaching.

\begin{abstract}
Media is closely related to the current economic and social development, while there often exists some deficiencies in the practical teaching of media in most universities. It has caused that the student's personal ability training is not comprehensive enough and they lack of certain practical ability. And they also have the problem of insufficient professional ability. This paper made some consideration with the practical teaching system of college media, combined with the research results of relevant scholars. And this paper summarized the corresponding countermeasures which are beneficial to the comprehensive development of college media, aiming at providing some useful thinking for the construction of this major.
\end{abstract}

\section{Preface}

The work of news media has important value and is a significant medium for the development of social information communication. With the development of China's economy, the practical function of news media is more perfect, and the function of cultural system construction and public opinion guiding has gradually been its main function. It is of great significance to the dissemination and effective utilization of information in the era of fragmentation. And the advent of the new media era makes information production and communication more rapid and changeable. The work of news media has well realized the collection and sharing of debris information. Along with the development change of news media work in the new era, college media, as the vital platform to train talents related to media, is supposed to strengthen the consideration of practical teaching system and the training of students' vocational abilities, keen smell for news and perfect professional morality to realize the promotion of students' abilities and real construction of media major.

\section{The necessity of practical teaching reform of college media under the new media environment}

\subsection{The Overall Quality and Ability of News Media Talents Are Disconnected with the Development of New Media Industry.}

TV news, radio, newspapers and other traditional media are all excellent information carriers before the development of the concept of new media. Particularly, TV news is used as the primary media to obtain local information and social news. And the accuracy, rapidity and officialization of its information source largely represent the development level of traditional media. However, the arrival of Internet information technology, especially the era of big data, has profoundly affected the operation and development of traditional media. Its functions gradually lack diversity, poor interaction with the information audience, and it cannot provide diversified services at the same time. At this time, the combination of new media and traditional media can compensate this deficiency. New media have changed the way people read and the need to read. The reception of information is everywhere, so is the action of reading and sharing information. Under this realistic background, the traditional teaching methods of news media pay more attention to theoretical teaching and analysis and inquiry, which undoubtedly lacks the training with students' abilities to adapt to the media work in the new media environment. For example, the public platforms of micro-blog and WeChat are used to hold online and offline activities to attract fans and better integrated into the new media environment by means of the creative and distinctive planning mode. While at present, colleges and 
universities mainly cultivate the basic professional abilities of writing and video shooting and production through the course system and internship. In the key vocational ability, college media personnel training, subject to various factors, appears willing but insufficient. Even though the basic ability is far from the practical skills required by the new media environment, for instance, short video shooting, long microblog writing, typesetting and editing and graphic design.

\subsection{The Concept of Practical Teaching Does Not Match the Overall Development of New Media Industry}

It is known that the practical teaching system of media in ordinary colleges and universities in China mainly includes writing course reports, completing course design, participating in course practice and designing graduation thesis. And the core is to focus on the basic course system of media, mainly aiming at training students understanding of relevant concepts, theories and practical applications of media and cultivating their corresponding abilities. However, the liberal arts nature of the media major makes it difficult for its experimental design to be carried out through specific exploratory experimental methods. And it's just a confirmatory experiment where students' self-consciousness and abilities are not fully developed, and the role and value of practical teaching are not close to students' future career needs to a large extent. It leads to that students lack the specific cognition with the environment of new media, and their concepts are only limited with the instant sharing software, for instance, micro-blog and We-chat, which is hard to deep into the kernel of the industry of new media, so the cognition with course innovation is insufficient in the process of actual application.

In addition, after the setting of media in most ordinary colleges, the corresponding practical teaching system is not unified with management rules, causing that its practical teaching is not only disconnected with the actual training requirements of applied talents of media but also far from the real development of new media industry. What needs to be clear is that the vital objective of practical teaching is to serve the course teaching and students' ability growth and better help students finish the change from theory learning to practical application and integrate into the modern media industry by means of the establishment of overall practical teaching system.

\subsection{The Experimental Conditions Are Backward and Cannot Be Integrated With the New Media Environment.}

Most ordinary local colleges are restricted by the educational qualifications and funding, as a result, the input of media experimental course is too limited, showing that the insufficient laboratory equipment (computer) quantity, fewer types, old equipment and delayed update. These reality gaps have made the experimental courses change from the personal operation to alternated operation or viewing teachers' operation. Students lack the real and enough participation sense, and they will lose their interests with professional courses just like that. At the same time, in the process of teachers' experimental operation, the adaptation and integration with new media environment cannot be well presented and the abilities of writing, editing, publishing, exhibition, analysis cannot be effectively exercised, making the teaching fail to be better carried out.

\section{Establish A Practical Teaching System for College Media under the New Media Environment}

\subsection{Apply the Information Materials and Strengthen the Compatibility of the New Media Environment.}

Higher education attaches great importance to strengthening the basic ability of professional talents and aims to cultivate students with learning awareness and innovation awareness, which requires that teachers should focus on students' mastering on the practical ability within the subjects in the practical teaching links, especially carrying out the practical teaching of media under the new media environment, getting familiar with the operation and publishing process of new media contents and having the simulated exercise and practice. In this process, first of all, we should pay attention to the innovation of the professional teaching material system of media and changing the incompatibility of the previous single paper textbooks with modern multimedia environment. For 
example, the application of "micro-course" system in practical teaching of media has greatly solved this problem. Micro-course is an important video teaching system, and modern media often needs different knowledge systems to cooperate with each other. Students often feel confused in the practical learning, while the application of micro-course video can greatly solve the problem. Students can make use of spare time to organize knowledge, complementary knowledge loophole and divide the concentrated learning time to a great extent through the APP of mobile phone or the embedded video links in We-chat, and they can have certain time to buffer and rest in the learning process of different contents. Such method can make students' negative emotions greatly weakened and better make the examination site and difficult point clear. Students can repeat learning and watching those concepts they don't understand, which can solve students' disturbance of the concentrated teaching of knowledge. At the same time, teachers can better cooperate with students to study and discuss the learning experiences and feelings preparing for the test. Then they can collect students' opinions, summarize those difficult contents students think in common and have careful explanation, which can greatly improve the efficiency of media teaching and be significant to saving students' learning time and promoting the efficiency.

Meanwhile, teachers are supposed to increase the propaganda and explanation of vocational ability and quality in the class teaching, constantly achieving the development on expanding the knowledge level of class teaching and gradually deepening the reform with media teaching resource under the new status. In addition, the accelerating function of traditional class teaching on students' knowledge should be highlighted to make students fully understand the requirements of practical teaching with media professionals and methods to realize.

\subsection{Reform the Way of Practical Teaching.}

As mentioned above, the reform of media teaching practice in ordinary colleges should be more targeted and the objective of training talents is those undergraduate talents with perfect knowledge ability quality. The goal of teaching training is also the goal of implementing teaching system construction. Therefore, it is necessary to take into account the current development status and future development direction of the school in the process of formulating specific practical teaching methods. At present, with the continuous expansion of the enrollment of undergraduate colleges, both the proportion of media enrollment and the actual enrollment have increased, but there are still many defects in the specific teaching practice. For instance, due to teachers' insufficient abilities and not enough awareness, the class teaching efficiency is rather low, and the teaching method of just reading textbooks has become the mainstream. So they fail to pull the teaching development through specific teaching cases, causing the increasing absence rate of students. For this problem, teachers should emphasize and apply different teaching methods, such as task-based teaching method and cooperative teaching method. At the same time, education of professional knowledge can also be carried out. It is recommended to arrange the course teaching according to a certain proportion when determining the practical teaching plan. For example, according to the teaching logic of teaching skills plus professional knowledge plus practical exercise and the proportion of 30\%, 50\% and 20\% to arrange practical teaching task, accelerate the benign interaction between teachers and students in the teaching process, truly realizing the target that practical teaching serves real teaching.

\subsection{Use the School-Enterprise Cooperation to Carry out The Practical Training and Accelerate the Formation of the Ordering Training Model.}

The practical training method of school-enterprise cooperation is of great significance to improve students' comprehensive qualities and form good professional abilities. College-enterprise cooperation can combine the superior educational resource around the college and form the training model of theory plus practice to enhance media students' understanding and grasp with practical knowledge using the famous teacher. In the process of internship outside school, students can better complete the digestion and absorption with theoretical knowledge and more comprehensively understand the teaching practice model of media based on the practical technology guidance of working environment of external guidance teachers. Thus, the proportion of practical operation can be strengthened through improving the university-enterprise cooperation and students' participation 
degree can be enhanced by means of practical patterns such as skills to play, to better form professional abilities and help students better adapt to the working post after graduation.

As an important driver of college professional education and course education, university-enterprise cooperation aims to make students solid their knowledge, strengthen practical abilities and have certain application and working abilities through real teaching practical environment, improving vocational students' real development and improve their real competitiveness.

Meanwhile, university-enterprise cooperation also is oriented in the development of high-quality course and exchange of practical teaching resource, making the graduates of media able to feel more professional new media working environment in advance, which contributes to training their professional attitudes and levels. For example, related teachers should be good at guiding the skill development of students to make students correctly understand the practical teaching process under the new media environment to truly achieve useful and excellent learning through practically participating in the planning of micro-blog activity, writing program plan and have off-line activities with short-videos.

The construction work of university-enterprise cooperation mode also can't forget the importance of system and supervision work. At the same time of attaching great importance to famous media teachers, the pure teaching environment and rigorous working and teaching atmosphere should be strictly ensured to highlight the professional and vocational features of vocational education. Through perfecting university-enterprise cooperation pattern in colleges and universities, the practical ability training will be paid more attention to in the actual practical process to form the media talents with both development of theoretical knowledge and ability training, which is of great significance to promote the comprehensive competitiveness of media students.

\section{Conclusions}

To sum up, college media professionals, as higher professional talents aiming at the market and serving the construction of news, are supposed to keep pace with the development of capabilities and the improvement of knowledge and culture quality, which reflects the core requirements of the innovative talent training model. Therefore, the structure and teaching module of practical teaching need to be changed specifically. This paper made the specific analysis with the practical teaching of college media and started from the construction of more effective practical teaching system to analyze the promotion of college media students' abilities and knowledge progress under the new media environment. It is aiming at further optimizing the training model of college media innovative talents through the research of this paper to strengthen the thinking on the professional construction and better promote the teaching service of college media. In addition, the connection between the actual development and demands of the media under the new media environment can be better highlighted in the real environment to promote the progress of news media work under the new media environment.

\section{References}

[1]. Yue Luo. Discussion on the construction of practical teaching system of college media under the new media environment [J]. Intelligence, 2018(08):109.

[2]. Qinghai Li. Research on the innovation of media talents training mode in colleges and universities under the context of media convergence [D]. Southwest University, 2017.

[3]. Fee Qi. A brief analysis on the construction of practical teaching system of college media under the new media environment [J]. Modernization of Education, 2017, 4(08):31-32+34.

[4]. Hong Jiang. Applied media talents cultivated by the integration of school and media - Taking the school of media in Meaning Normal University as an example [J]. Journal of meaning normal university, 2016, 35(07):59-63. 
[5]. Zima Wang. A preliminary study on the development of college media major in ethnic minority areas in the era of "Internet plus" -- Taking Guizhou Institute of Engineering Application Technology for an example [J].Western broadcast television, 2015(18):36+41.

[6]. Yawn Zhao, Yu Zhang, Zhan Feng and Qing Jun Ren. Quality analysis and model research on media talents training in Chinese universities -- Take universities of Tianjin as examples [J]. Journalistic University, 2013(06):139-149. 